\title{
Interactions between two species of saltmarsh gastropod, Hydrobia ulvae and Littorina littorea
}

\author{
C. L. J. Frid, R. James \\ School of Biological Sciences, University of East Anglia, Norwich NR4 7TJ, United Kingdom
}

\begin{abstract}
On a submergent saltmarsh on the coast of eastern England the gastropods Hydrobia ulvae and Littorina littorea co-exist. Interactions between these species were investigated using both laboratory and field experiments. Removal of L. Iittorea from patches of intertidal gravel for 3 mo had no effect on $H$. ulvae density, but led to an increase in the density of infaunal oligochaetes and a decrease in Tetrastemma spp. and Capitella spp. In cleared patches L. littorea had returned to original densities by ca $14 \mathrm{~d}$ after clearing, indicating a moderate mobility of these populations. Manipulations of field densities of $H$. ulvae suggested that populations in most marsh habitats were limited by densitydependent processes. Examination of the size spectra of particles ingested demonstrated a degree of partitioning of the food resource by particle size. Habitat preference experiments further demonstrated a strong behavioural preference of $L$. littorea for gravel deposits, and of $H$. ulvae for fine mud substrata. Potential interspecific competition between these species is moderated by both resource partitioning and a behavioural mechanism leading to spatial separation.
\end{abstract}

\section{INTRODUCTION}

The extent and significance of interspecific competition in nature has been the subject of much debate (Connor \& Simberloff 1979, Strong et al. 1979, Schoener 1982, 1983, Connell 1983, Roughgarden 1983). Many ecological studies have concentrated on mechanisms whereby available resources are partitioned amongst co-existing species (e.g. Cody 1968, Fenchel 1975). In a few cases competition in the field has been inferred from character displacement. The deposit-feeding mudsnails (Hydrobiidae) have been shown to (1) partition the food resource, by means of particle size, with the co-occurring amphipod Corophium volutator (Fenchel et al. 1975), and (2) undergo character displacement, to reduce competition, in the presence of congeners (Fenchel 1975, but see also Hylleberg 1986, Cherrill \& James 1987).

On the extensive saltmarshes of the North Norfolk coast, in eastern England, 2 species of gastropod commonly co-occur on the submergent saltmarsh. The mudsnail Hydrobia ulvae (Pennant) (hereafter $H$. ulvae) is widely distributed over the marsh, feeding predominantly as a surface-deposit feeder but also as an epipsammic grazer on particles too large to be ingested (Levinton \& Lopez 1978). H. ulvae has been recorded from a wide range of substrata, ranging from fine organically rich mud through sands to deposits of glacial gravel and even bedrock surfaces (Barnes \& Greenwood 1978). It commonly colonizes macroalgae such as Ulva, Enteromorpha and even fucoids when they are present (Barnes \& Greenwood 1978, Barnes 1979). The common edible periwinkle, Littorina littorea (L.) (hereafter L. Littorea), also occurs on the submergent (= lower) saltmarsh. Its distribution is more restricted, generally being associated with glacial gravel deposits or areas of mud adjacent to these deposits (Frid 1988). It is primarily a rocky intertidal species, and it feeds as an epistrate grazer (Watson \& Norton 1985). L. littorea is also able to feed as a deposit feeder (Graham 1971).

H. ulvae and L. littorea are potentially in competition for the same resource (detrital particles and benthic diatoms). Field manipulations of their densities were used to assess the degree of food limitation of surfacedeposit feeders and to determine if any competitive release occurs.

If resources are limiting, competition may be lessened through the division of resources, e.g. by particle size or by spatial separation of the competitors. In view of the disparity in size of adults of the 2 species (H. ulvae $\approx 5 \mathrm{~mm}$; L. littorea $\approx 20 \mathrm{~mm}$ ) it would seem likely that $L$. littorea would utilize particles above the maximum size ingestible by $H$. ulvae (i.e. $63 \mu \mathrm{m}$; Fen- 
chel 1975). However the larger the particle the smaller the relative biomass of associated micro-organisms. Hence larger particles should be less attractive as a food source. In this study competition between $H$. ulvae and $L$. littorea was investigated by comparisons of the size distribution of ingested particles.

Moderation of competition in the field by means of spatial separation within the saltmarsh habitat is also possible. Previous studies (Newell 1962, 1965, Fenchel 1975, Barnes \& Greenwood 1978, Barnes 1979) have demonstrated a behavioural preference in $H$. ulvae for sediments composed of fine particles. Investigations of the behavioural preferences of $L$. littorea have centered on its food preferences when on a bedrock substrate (e.g. Watson \& Norton 1985). We investigate possible lessening of competition by means of behavioural preferences using simple choice chamber experiments, offering a choice of natural mud or natural gravel/ pebble substrata.

\section{MATERIALS AND METHODS}

Experimental animals were collected from, and the field experiments were carried out on, the submergent saltmarsh at Stiffkey (Ordnance Survey reference TF965449) in eastern England.

Manipulation of $\boldsymbol{H}$. ulvae densities. On 7 and 8 July 1986, 2 pairs of cages were placed in each of the following marsh habitats: Habitat 1: salt pans/pools; Habitat 2: vegetated (mainly Spartina) marsh; Habitat 3: mainly unvegetated marsh (some seasonal growth of Salicornia); and Habitat 4: areas of glacial gravel deposits. Cages were $1.07 \times 0.85 \times 0.55 \mathrm{~m}$, and consisted of a wooden frame meshed with $2 \mathrm{~mm}$ 'NETLON'. The cages were set into the sediment to a depth of $20 \mathrm{~cm}$

One of each pair of cages was randomly selected as the control. The control cage was closed containing ambient densities of $H$. ulvae. An area of $4.28 \times 0.85 \mathrm{~m}$ was marked out in the habitat adjacent to the cage and the surface $5 \mathrm{~mm}$ of sediment was sieved through a $500 \mu \mathrm{m}$ sieve. The H. ulvae retained on the sieve were added to the experimental cage to give an approximate 5 -fold increase in $H$. ulvae density. No other organisms were added or removed.

After 3 mo (14 October 1986) the cages were sampled, by taking three $6 \mathrm{~cm}$ diameter cores randomly within each cage. These were immediately returned to the laboratory, sieved $(500 \mu \mathrm{m})$ and the retained gastropods placed into dishes of clean seawater. The number of living individuals of $H$. ulvae and $L$. littorea were counted. Three cores were also drawn from uncaged areas of each habitat at the commencement and termination of the experiment.

L. littorea removal and recolonization. On 8 July
1986 three $1 \mathrm{~m} \times 1 \mathrm{~m}$ areas were marked out on an area of glacial gravel on the submergent marsh. Each area was marked by a wooden post driven into the sediment at each corner. Each area was cleared of $L$. littorea by careful searching. The number removed was recorded. The areas were searched and cleared of $L$. littorea on 4 subsequent occasions, the time interval being varied to assess the rate of recolonization.

On 28 August 1986 the experiment was terminated. Each area was searched and the number of $L$. littorea recorded, and three $6 \mathrm{~cm}$ diameter cores were drawn randomly from the central $0.5 \times 0.5 \mathrm{~m}$ of the area, to avoid any boundary effect. Three cores were taken from adjacent areas of the habitat on 8 July, and 5 and 28 August. Cores were fixed in $70 \%$ alcohol containing $5 \%$ Rose Bengal. Cores were subsequently sieved (500 $\mu \mathrm{m})$ and the macrofauna enumerated.

Size spectra of particles ingested. H. ulvae were collected from sites on the marsh where they occurred allopatrically with respect to $L$. Littorea. In addition both species were collected together from sympatric sites. Specimens were maintained on the sediment from which they were collected - allopatric snails allopatrically and sympatric snails sympatrically - in aquaria at $14^{\circ} \mathrm{C}$ under a $16 \mathrm{~h}$ light: $8 \mathrm{~h}$ dark regime.

Crystallizing dishes (12 cm diameter) were filled with natural sediment to a depth of $5 \mathrm{~mm}$, and $31 \%$ natural seawater added to a depth of $5 \mathrm{~mm}$. These were allowed to 'age' for $24 \mathrm{~h}$. Benthic diatoms are highly mobile and very fecund (Gray 1981), so this period allowed natural populations to become established in the upper sediment layers.

The experimental animals were transferred to dishes containing clean seawater (no sediment) and allowed to clear their guts for $4 \mathrm{~h}$. The seawater was changed once during this period. The animals were then transferred to the dishes with sediment. The following experimental treatments were set up: (1) 25 allopatric $H$. ulvae in a dish; (2) 25 sympatric $H$. ulvae in a dish; (3) 5 sympatric $L$. littorea in a dish; (4) 20 sympatric H. ulvae and 3 sympatric L. Littorea together in a dish. Each treatment was replicated a total of 10 times.

The animals were allowed to feed for $2.5 \mathrm{~h}$, at the end of which they were transferred to solid watch glasses containing clean seawater. Individuals of each species from Treatment 4 were kept separately. After $4 \mathrm{~h}$ the faecal pellets were removed and the size spectrum of at least 100 particles from at least 2 pellets from each replicate was determined.

Substratum preference. Experiments were carried out using $14 \mathrm{~cm}$ diameter crystallizing dishes, which had previously been fitted with internal partitions of $1 \mathrm{~cm}$ height, dividing them into 4 quadrants (approximate area $36 \mathrm{~cm}^{2}$ each). Sediments were distributed amongst the quadrants according to the scheme 
devised by Barnes \& Greenwood (1978), and illustrated in their Fig. 1. Quadrants labeled A and B in the figure were gravel filled, and quadrants $C$ and $D$ were mud filled. The characteristics of the sediments are summarized in Table 1 . The quadrants were filled to

Table 1. Characteristics of the sediments used

\begin{tabular}{|lcccc|}
\hline Substrata & $\begin{array}{c}\text { Median } \\
\text { diameter } \\
\text { (phi) }\end{array}$ & $\begin{array}{c}\text { Quartile } \\
\text { deviation }\end{array}$ & $\begin{array}{c}\% \\
\text { Organics }\end{array}$ & $\begin{array}{c}\% \\
\text { Silt/clay }\end{array}$ \\
\hline Mud & 1.35 & 0.84 & 16.26 & 18.60 \\
Gravel & -0.82 & 0.34 & 8.32 & 8.90 \\
\hline
\end{tabular}

the level of the divisions with sediment and covered with $31 \%$ natural seawater to an approximate depth of $5 \mathrm{~mm}$.

The enclosures were allowed to age for $24 \mathrm{~h}$ before the experiments were carried out at $14^{\circ} \mathrm{C}$ and under $16 \mathrm{~h}$ light: $8 \mathrm{~h}$ dark. The experiment of 12 enclosures was repeated twice with each of the following regimes: (1) 3 L. Iittorea only; (2) $20 \mathrm{H}$. ulvae only; (3) $20 \mathrm{H}$. ulvae and $3 \mathrm{~L}$. littorea. An experiment was initiated by placing the snails in the centre of the enclosure. Each experiment was run for $48 \mathrm{~h}$ after which the number of snails of each species on each substratum were counted. The number of snails climbing the enclosure wall or, in the case of $H$. ulvae, floating at the water surface, were also recorded.

\section{RESULTS}

\section{Manipulation of $H$. ulvae densities}

With the exception of the gravel habitat, $H$. ulvae numbers were significantly lower in caged than uncaged controls (Table 2). In 3 habitats, with the exception of pools, cage densities of $H$. ulvae were not significantly different whether or not they had been initially increased by 5 -fold - the manipulated increase did not persist. Densities and variability in the open areas of all 4 habitats were similar, whereas in the caged areas there was obvious variation in densities.

L. littorea densities on gravel were higher in cages than in the open, especially where $H$. ulvae densities had been initially increased.

\section{L. littorea removal and recolonization}

The number of $L$. littorea that recolonized each cleared area increased with time since last clearance up to 10 or $14 \mathrm{~d}$ (Fig. 1). In the one set of samples taken after $23 \mathrm{~d}$ the density of $L$. littorea had decreased. However at this value does not differ significantly from control values recorded at the time (Mann-Whitney U, $p>0.05)$, it reflects ambient densities at the sampling date. These results indicate that $L$. littorea is sufficiently mobile within the marsh to recolonize cleared areas within one spring-neap tidal cycle.

Throughout the experiment the relative densities of L. littorea in each area were consistent. Area 3 densities

Table 2. Densities of gastropods (individuals per core \pm SE) in control areas, caged controls and experimental cages stocked to $5 \times$ natural density, after 3 mo enclosure $(n=6)$. Significance tested $(p<0.05)$ by Kruskall-Wallis for A, B and C together, denoted $\mathrm{KW}^{*}$, and Mann-Whitney for paired comparisons, denoted $\mathrm{A}>\mathrm{B}$ etc.

\begin{tabular}{|c|c|c|c|c|}
\hline Species \& habitat & $\begin{array}{c}\text { A } \\
\text { Uncaged controls }\end{array}$ & $\begin{array}{c}\text { B } \\
\text { Caged natural } \\
\text { density }\end{array}$ & $\begin{array}{c}\mathrm{C} \\
\text { Experimental cages at } \\
5 \times \text { natural density }\end{array}$ & Significance \\
\hline \multicolumn{5}{|l|}{ Hydrobia ulvae } \\
\hline Mud (Habitat 1) & $8.50 \pm 2.20$ & $0.17 \pm 0.17$ & $0.33 \pm 0.21$ & $\begin{array}{l}K W^{\circ} \\
A>B, A>C\end{array}$ \\
\hline Vegetation (Habitat 2) & $6.17 \pm 2.06$ & $0.50 \pm 0.50$ & $3.83 \pm 1.99$ & $\begin{array}{l}K W \\
A>B, A>C\end{array}$ \\
\hline Pool (Habitat 3) & $8.33 \pm 2.36$ & 0 & $20.17 \pm 5.9$ & $\begin{array}{l}K W^{*} \\
A>B, C>A, C>B\end{array}$ \\
\hline Gravel (Habitat 4) & $5.83 \pm 2.04$ & $14.0 \pm 6.96$ & $2.83 \pm 1.14$ & NS \\
\hline $\begin{array}{l}\text { Littorina littorea } \\
\text { Gravel (Habitat 4) }\end{array}$ & $0.17 \pm 0.17$ & $2.00 \pm 0.86$ & $2.70 \pm 0.62$ & $\begin{array}{l}\mathrm{KW} \\
\mathrm{C}>\mathrm{A}\end{array}$ \\
\hline
\end{tabular}




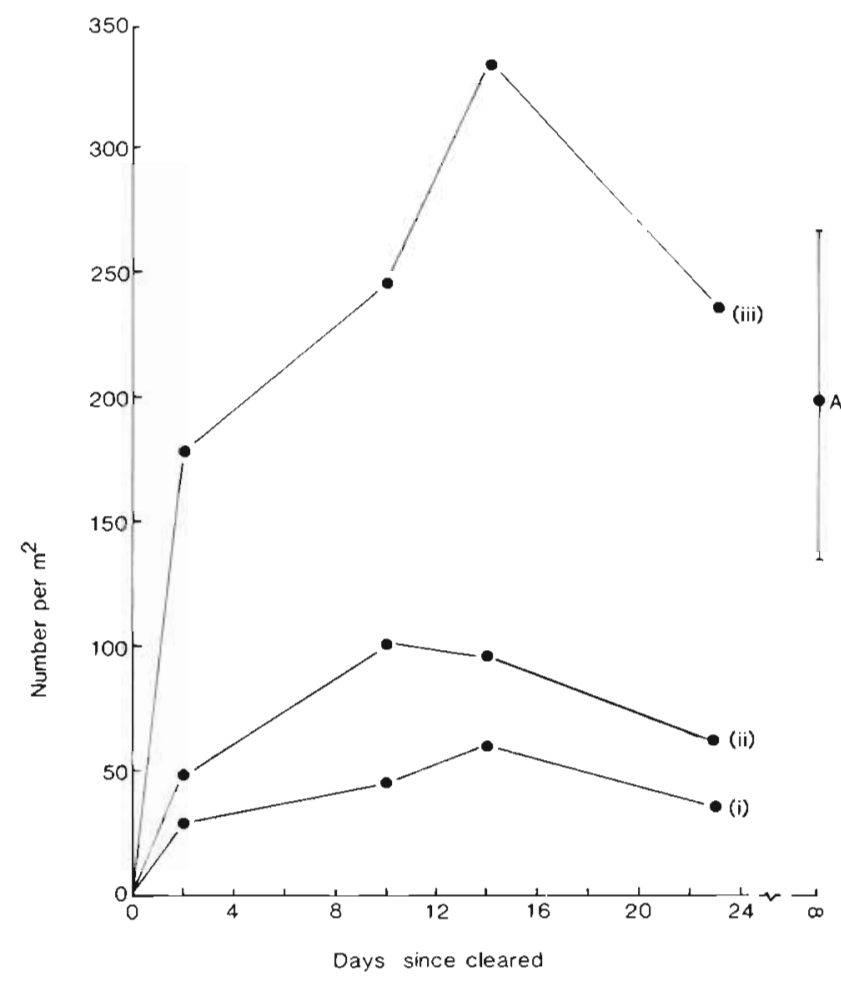

Fig. 1. Littorina littorea. Recolonisation of three $1 \mathrm{~m}$ square areas [(i) to (iii)] of glacial gravels in a saltmarsh. Point $\mathrm{A}=$ mean density in control areas $( \pm S E)(n=9)$

exceeded those in Area 2, which in turn had higher densities than Area 1.

Faunal densities within the areas of lowered mean L. littorea density (Table 3) show significant effects of L. littorea only on Capitella capitata Fabricius, the oligochaetes, and Tetrastemma spp. C. Capitata, the tubificid oligochaetes (mainly Tubifex costatus Claparede), and the 'other' oligochaetes (mainly Enchytraeidae) showed a significant increase in the

Table 3. Faunal densities within areas of intertidal gravel from which Littorina littorea had been removed, and unmanipulated controls at the end of the experiment $(n=9)$. Significance assessed at $\alpha=0.05$, 2-tailed Mann-Whitney $U$

\begin{tabular}{|c|c|c|c|}
\hline \multirow{2}{*}{$\begin{array}{l}\text { Species } \\
\text { Littorina littorea }\end{array}$} & $\begin{array}{l}\text { Density (ino } \\
\text { Removal } \\
\text { area }\end{array}$ & $\begin{array}{c}\left.\mathrm{m}^{-2} \pm \mathrm{SE}\right) \\
\text { Control } \\
\text { area }\end{array}$ & $\begin{array}{l}\text { Signifi- } \\
\text { cance }\end{array}$ \\
\hline & $78 \pm 26.0^{\circ}$ & $197 \pm 65.5$ & Sig. \\
\hline Hydrobia ulvae & $1297 \pm 432.3$ & $2437 \pm 812.0$ & NS \\
\hline Tubifex spp. & $472 \pm 157.0$ & $39 \pm 13.1$ & Sig. \\
\hline Other oligochaetes & $354 \pm 118.0$ & $79 \pm 26.2$ & Sig. \\
\hline Tetrastemma spp. & $39 \pm 13.1$ & $432 \pm 144.0$ & Sig. \\
\hline Capitella capitata & $236 \pm 78.6$ & 0 & Sig. \\
\hline \multicolumn{4}{|c|}{$\begin{array}{l}\text { - Sample consisted of juveniles }<2.0 \mathrm{~mm} \text { maximum di- } \\
\text { mension }\end{array}$} \\
\hline
\end{tabular}

absence of L. Littorea, whereas Tetrastemma showed a decrease.

Therefore the presence of $L$. littorea had some effect on community structure, but no effect on densities of the surface deposit feeder H. ulvae.

\section{Size spectra of particles ingested}

Data were analysed using SPSS-x on the Cambridge University Data Network. A multivariate 3-way ANOVA (SPSS-x MANOVA procedure) of particle size class against species, by ecological source, by experimental treatment (i.e. maintained allopatrically or sympatrically during the experiment) showed (1) a significant effect of species on size class utilization $(p<0.05)$, (2) no significant effect of ecological condition either in the field or during the experiment. The interaction terms were not significant.

From these results (Fig. 2) it can be seen that while $L$. littorea and $H$. ulvae used the same range of particle sizes, L. littorea used significantly more of the larger

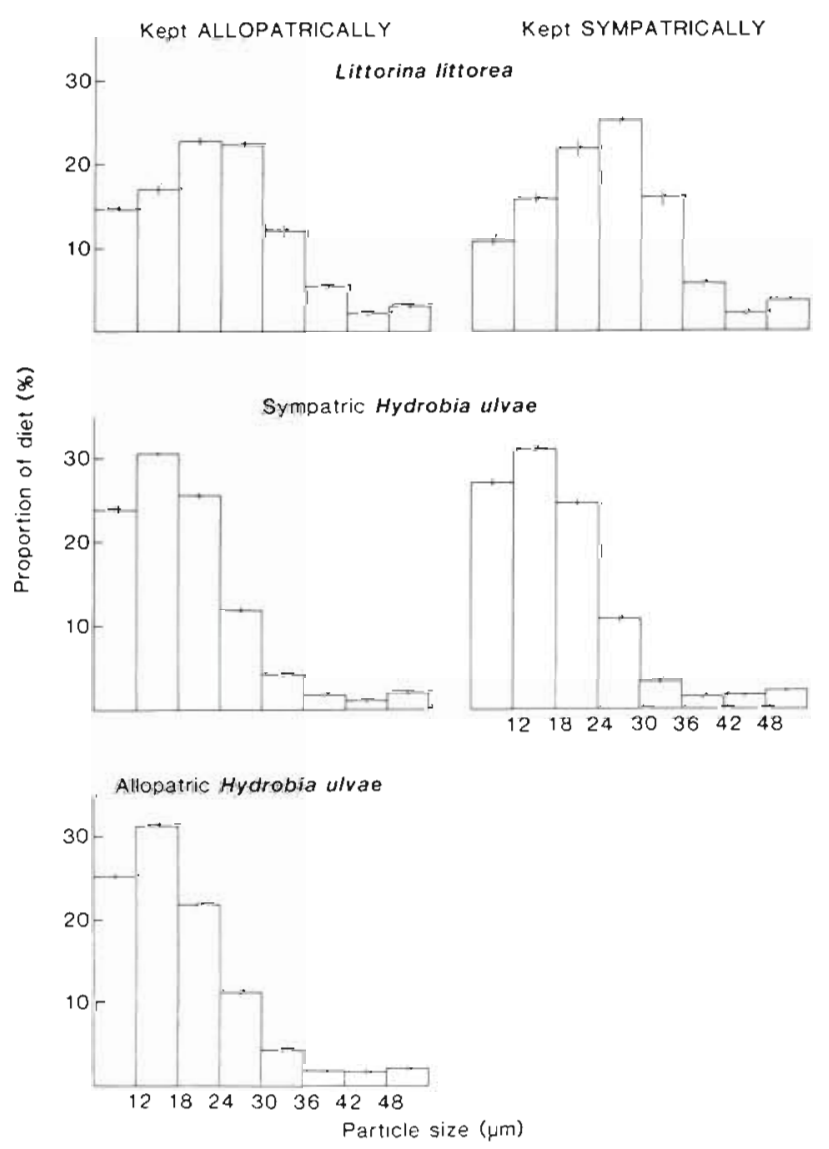

Fig. 2. Littorina littorea and Hydrobia ulvae. Resource use by snails from different sources maintained sympatrically and allopatrically. (Bars indicate SE) 
size classes. There remains, however, considerable overlap in their resource use.

\section{Substratum preference}

Results are expressed in terms of the 24 replicates per treatment (Table 4). There was no significant difference between the 2 experiments of 12 replicates each for any given treatment (ANOVA $\mathrm{p}>0.05$ )

Table 4. Littorina Littorea and Hydrobia ulvae. Mean ( \pm SE) number of snails on each substratum after $48 \mathrm{~h}$. ( $\mathrm{n}=24$ replicates)

\begin{tabular}{|c|c|c|c|}
\hline \multirow{2}{*}{$\begin{array}{l}\text { Species } \\
\text { (source) }\end{array}$} & \multicolumn{3}{|c|}{ Mean number of snails ( \pm SE) } \\
\hline & Gravel & Mud & $\begin{array}{c}\text { Sides/ } \\
\text { floating }\end{array}$ \\
\hline $\begin{array}{l}\text { L. Littorea } \\
\text { (allopatric) }\end{array}$ & $2.20 \pm 0.15$ & 0 & $0.79 \pm 0.13$ \\
\hline $\begin{array}{l}\text { H. ulvae } \\
\text { (allopatric) }\end{array}$ & $5.33 \pm 0.37$ & $10.48 \pm 0.43$ & $5.06 \pm 0.38$ \\
\hline $\begin{array}{l}\text { L. littorea } \\
\text { (sympatric) }\end{array}$ & $1.33 \pm 0.21$ & $0.04 \pm 0.04$ & $1.63 \pm 0.22$ \\
\hline $\begin{array}{l}\text { H. ulvae } \\
\text { (sympatric) }\end{array}$ & $3.54 \pm 0.40$ & $13.04 \pm 0.54$ & $3.42 \pm 0.32$ \\
\hline
\end{tabular}

The number of snails, of each species on each substratum was compared (1-way ANOVA, Student-Newman-Keuls multiple range test), the null hypothesis being that if the distribution of snails were random the numbers on each substratum would be equal. $L$. littorea showed a significant preference for gravel over either mud or the container sides, and selected the sides in preference to the mud. H. ulvae showed a significant preference for the mud, but did not distinguish between the sides and the gravel (Tables 4 and 5).

Table 5. Littorina littorea and Hydrobia ulvae. Significant (Student-Newman-Keuls range test, $\alpha=0.05$ ) differences in substratum preference, denoted ${ }^{*}$

\begin{tabular}{|lccc|}
\hline Species & $\begin{array}{c}\text { Gravel vs } \\
\text { sides }\end{array}$ & $\begin{array}{c}\text { Gravel vs } \\
\text { mud }\end{array}$ & $\begin{array}{c}\text { Mudvs } \\
\text { sides }\end{array}$ \\
\hline $\begin{array}{l}\text { L. littorea } \\
\text { H. ulvae }\end{array}$ & NS & - & $\cdot$ \\
NS: not significant & & . \\
\hline
\end{tabular}

These behavioural preferences were consistent irrespective of the presence in the enclosure of the other species (Mann-Whitney $U, p<0.005$ ).

\section{DISCUSSION}

Hydrobia ulvae is one of the most abundant intertidal organisms on the saltmarshes of the North Norfolk coast, eastern England (Bames \& Greenwood 1978). As such it is likely to play an important role in the dynamics of the intertidal invertebrate community. The work of Fenchel and co-workers (e.g. Fenchel 1975, Fenchel et al. 1975) has emphasized the interactions within the Hydrobiidae (Fenchel 1975) and between $H$. ulvae and a co-occurring amphipod on tidal flats (Fenchel et al. 1975). In both cases it was shown that the species partition food resources on the basis of particle size.

If detrital particles are a limiting resource, then 2 species simultaneously trying to exploit them may enter into interspecific competition. As competitive exclusion is not occurring, the mechanism moderating the effects of competition must be sought. The data presented here reveal some partitioning of food resources on the basis of particle size, but there is considerable overlap in the resources used by the 2 species. The ecological condition, i.e. sympatry vs allopatry, of the organisms either during the experiment or originally in the field had no effect on their subsequent resource use. The maximum degree of similarity in resource use which can still allow co-existence is a matter of debate amongst theoretical ecologists (Sale 1974, Armstrong \& McGehee 1976). H. ulvae and L. littorea do, however, co-exist in the field. Further reduction in the density of L. Littorea did not lead to an increase in the population of $H$. ulvae (Table 3), and there was no competitive release on the gravel substrata.

The significant increase in Capitella capitata and both tubificid and other oligochaetes in the L. littorea removal deserves further investigation. A possible cause of this increase is the suppression of C. capitata and oligochaetes, at natural densities of $L$. littorea, by periwinkles moving from the preferred large particles on to the mud matrix in response to intraspecific competition. Here they may compete with the infauna. The interactions between $L$. littorea and the infaunal species warrant further investigation.

Caging experiments in soft sediment environments are fraught with difficulties (Virnstein 1978, Peterson 1979, Hulbert \& Oliver 1980). The cages used in the increased $H$. ulvae density manipulation introduced a significant caging effect. This could have resulted from a cage-induced environmental change (Hulbert \& Oliver 1980), or the cages may also have imposed a direct mortality on the enclosed populations. For example, H. ulvae avoids ingesting fecal material, and at high densities the entire sediment surface can become pelletized (Levinton \& Lopez 1978). This would increase the amount of intraspecific competition for 
food. Additionally, as the cages were in place for 6 sets of neap tides, the mid-marsh areas receive no tidal cover for 3 to $5 \mathrm{~d}$ around neaps. The cages may have prevented $H$. ulvae individuals from spending this period in more benign areas and so have increased the mortality due to desiccation. The former process is density dependent while the latter is density independent.

Our results (Table 2 ) show generally no significant difference in $H$. ulvae densities between cages where initial densities had been increased 5 -fold and those at normal densities. In spite of the caging effect noted above, this suggests that density-dependent limitation of $H$. ulvae numbers was probably occurring within the cages in most marsh habitats studied here. Levinton \& Lopez (1978) have argued that food is usually limiting for populations of intertidal surface-deposit feeders. We therefore consider it is likely that, over most of the saltmarsh, populations of $H$. ulvae become food limited when their normal mobility is removed.

Partitioning of the habitat into a series of $\mathrm{mi}$ crohabitats by means of temporal or spatial separation of the competitive species can act to alleviate competition. Field data (Frid 1988) show no evidence of temporal partitioning. Both species show an annual minimum in winter, increasing simultaneously in late spring/early summer. However field data did reveal an association of $L$. littorea with gravel deposits. The results of our laboratory experiments to investigate the mechanism, if any, of this association (Tables 4 and 5) indicated a clear preference in $H$. ulvae for natural mud substrata, and in L. littorea for natural gravel substrata. Although $H$. ulvae show a clear preference for mud they also occur in low numbers on the gravel of the laboratory enclosures and the field. L. littorea occur on mud in the field but avoid it in the trials to the extent that only 1 individual, out of the 144 used, was found on mud after $48 \mathrm{~h}$ !

We do not propose that it is the nature of the substratum per se that acts to moderate competition, but correlated changes in the nature of the food resource. In the fine organically rich mud there are abundant detrital particles harbouring microbial communities. These microbial communities are the portion utilized by deposit feeders. The gravel deposits are composed of a matrix of fine particles, including detrital particles, and larger $(>2 \mathrm{~cm})$ particles, that support on their surface an epiflora of diatoms which are available for grazing

We conclude therefore that while $L$. Iittorea and H. ulvae may potentially compete for food, in the field this is moderated by (a) some partitioning of the food resource by means of particle size discrimination, and (b) by strong behavioural preferences for different substrata. H. ulvae prefers fine organically rich mud deposits, where it feeds predominantly on benthic diatoms and bacteria associated with detrital particles. It also grazes epipsammically on larger particles. In contrast L. Littorea prefers deposits of large particles, where it feeds predominantly by grazing the covering of algal sporelings and diatoms, in a manner analogous to its feeding behavior on a rocky shore.

Acknowledgements. This work was carried out while CLJF was in receipt of SERC award 84317080 and a University of East Anglia graduate studentship. We thank the Nature Conservancy Council for permission to work within the National Nature Reserve at Stiffkey and Sue Mitchell for drawing the figures. The manuscript was improved thanks to Bill Sutherland, Colin Townsend and the anonymous reviewers.

\section{LITERATURE CITED}

Armstrong, R. A., McGehee, R. (1976). Coexistence of species competing for shared resources. Theoret. Pop. Biol. 9: 317-328

Barnes, R. S. K. (1979). Intrapopulation variation in Hydrobia sediment preference. Estuar. coast. mar. Sci. 9: 231-234

Barnes, R. S. K., Greenwood, J. G. (1978). The response of the intertidal gastropod Hydrobia ulvae (Pennant) to sediments of differing particle size. J. exp. mar. Biol. Ecol. 31 43-54

Cherrill, A. J., James, R. (1987). Character displacement in Hydrobia. Oecologia (Berl.) 71: 618-623

Cody, M. L. (1968). On methods of resource division in grassland bird communities. Am. Nat. 102: 107-148

Connell, J. H. (1983). On the prevalence and relative importance of interspecific competition: evidence from field studies. Am. Nat. 122: 661-696

Connor, E. F., Simberloff, D. (1979). The assemblage of species communities: chance or competition? Ecology 60 $1132-1140$

Fenchel, T (1975). Character displacement and co-existence in mud snails (Hydrobiidae). Oecologia (Berl.) 20: 19-32

Fenchel, T., Kofoed, L. H., Lappalainen, A. (1975). Particle size selection of two deposit feeders: the amphipod Corophium volutator and the prosobranch Hydrobia ulvae. Mar. Biol. 30: $119-128$

Frid, C. L. J. (1988). The marine fauna of the salt marshes of North Norfolk, and their ecology. Trans. Norf. Norw. nat. soc. (in press)

Graham, A. (1971). British prosobranchs and other operculate molluscs. Linn. Soc. Guide No. 2. Academic Press, London

Gray, J. S. (1981). The ecology of marine sediments: an introduction to the structure and function of benthic communities. Cambridge University Press, Cambridge

Hulbert, L. W., Oliver, J. S. (1980). Caging manipulations in marine soft-bottom communities: importance of animal interactions or sedimentary habitat modifications. Can. J. Fish Aquat. Sci. 37: 1130-1139

Hylleberg, J. (1986). Distribution of Hydrobiid snails in relation to salinity, with emphasis on shell size and co-existence of the species. Ophelia suppl. 4: 85-100

Levinton, J. S., Lopez, G. R. (1978). A model of renewable resources and limitation of deposit-feeding benthic communities. Oecologia (Berl.) 31.177-190

Newell, R. C. (1962). Behavioural aspects of the ecology of Peringia (= Hydrobia) uIvae. Proc. Zool. Soc. Lond. 138: $49-75$ 
Newell, R. C. (1965). The role of detritus in the nutrition of two deposit feeders, the prososbranch Hydrobia ulvae and the bivalve Macoma balthica. Proc. Zool. Soc. Lond. 144: $25-45$

Peterson, C. H. (1979). Predation, competitive exclusion and diversity in the soft sediment benthic communities of estuaries and lagoons. In: Livingston, R. J. (ed.) Ecological processes in coastal and marine systems. Plenum Press. New York, p. 233-264

Roughgarden, J. (1983). Competition and theory in community ecology. Am. Nat. 122: 583-601

Sale, P. F. (1974). Overlap in resource use, and interspecific competition. Oecologia (Berl.) 17: 245-256
Schoener, T W. (1982). The controversy over interspecific competition. Am. Sci. 70: 586-595

Schoener, T W (1983). Field experiments on interspecific competition. Am. Nat. 122: 240-285

Strong, D. R., Szyska, L. A., Simberloff, D. (1979). Tests of community wide character displacement against null hypotheses. Evolution 33: 897-913

Virnstein, R. W. (1978). Predator caging experiments in soft sediments: caution advised. In: Wiley, M. L. (ed.) Estuarine interactions. Academic Press, New York, p. 261-273

Watson, D. C., Norton, T. A. (1985). Dietary preference of the common periwinkle Littorina littorea (L.) J. exp. mar. Biol. Ecol. 88: 193-211

This article was presented by Professor J. S. Gray; it was accepted for printing on December 15, 1987 